\title{
DR. JARMILA EMMEROVÁ - VZPOMÍNKY Z OBDOBÍ PO LISTOPADU 1989
}

\author{
PhDr. TOMÁŠ MÍKA, \\ PŘEKLADATEL, BÁSNÍK, VYSOKOŠKOLSKÝ PEDAGOG
}

Na podzim roku 1989 jsem začal učit na katedře překladatelství a tlumočnictví FF UK. Přihlásil jsem se v létě toho roku do konkursu na místo odborného asistenta na této katedře a byl jsem přijat. Došlo k tomu takto: Zavolal mi Petr Janyška a upozornil mě na konkurs. On sám prý na katedře nějakou dobu pracoval, ale poté, co podepsal petici Několik vět, nebyla mu prodloužena smlouva na další akademický rok a at to prý zkusím já. „Ale já taky podepsal Několik vět, “ ríkám mu. „To nevadí, zkus to, třeba to o tobě ještě nevědí.“ Zkusil jsem a vyšlo to. Fajn, říkal jsem si. Nové dobrodružství devětadvacetiletého nedávného absolventa oboru angličtina - čeština. Pro dokreslení doby zmíním, že kádrovák na FF UK, který připravoval mou smlouvu, po mně mimo jiné chtěl posudek základní komunistické organizace z předchozího zaměstnání. Tím byla Jazyková škola v Praze 4, kde žádní komunisté nebyli. Nezapomenu na povislou čelist onoho soudruha, když jsem mu tuto informaci sděloval, a jeho rozčílené: „Jak to, že tam komunistická organizace není!“ Byla to předzvěst měnících se časů, ale to jsem ještě nevěděl. Nakonec mi dali s jistým zpožděním smlouvu i bez komunistického dobrozdání a já začal učit zprvu jen dva semináře - technický překlad a volitelný seminář, který jsem si vybral sám - překlady poezie. A začal jsem se vídat s paní doktorkou Emmerovou. Věděl jsem, kdo je. Předcházela ji pověst skvělé překladatelky a pedagožky, přítelkyně Josefa Škvoreckého a Jana Zábrany. Bylo známo, že po osmašedesátém byla na KPT „odsunuta“ $\mathrm{z}$ anglistiky, nebot byla „ideologicky nespolehlivá“. To všechno byly pro mě ovšem samé plusy.

Naše kontakty nabraly na intenzitě po 17. listopadu 1989. Již v sobotu 18. listopadu jsme se s dr. Emmerovou neplánovaně sešli před kolejemi na Větrníku, kam nás, každého zvlášt, pozvali studenti katedry, kteří zde spolu s dalšími plánovali stávku. Nepřekvapilo mě, že tam potkávám právě ji.

Následoval dobře známý první týden studentské stávky, masových demonstrací, překotného politického vývoje. Všude na Filozofické fakultě se scházely katedry a řešily tak či onak aktuální situaci. Tř́bily se charaktery. Katedra překladatelství a tlumočnictví v Hybernské působila poněkud hibernovaně. Nedělo se tam nic. První schůze katedry se konala až druhý týden studentské stávky. Vedoucí katedry a zároveň proděkan FF UK, profesor Milan Hrala, na ní vyzýval k opatrnosti. O dva měsíce později tentýž profesor Hrala $v$ den Palachova výročí řečnil před shromážděným davem na dnešním Palachově náměstí (dříve Náměstí Krasnoarmějců).

Jednoznačné nadšení z hroutícího se systému nás projevovalo jen několik, např. dr. Josef Forbelský, Halka Hritzová a ovšem dr. Emmerová, která svou podporu studentské 
stávce a právě vytvořenému hnutí Občanské fórum dávala bez rozpaků veřejně najevo. Studenti k ní vždy přirozeně tíhli a $\mathrm{v}$ této bouřlivé době zejména pro ně byla opěrným bodem, pedagogem, kterému věřili, člověkem, jehož názory byly jasné a neskrývaně přitakávající probíhajícím změnám. Bylo přirozené, že když o půl roku později, zhruba v době prvních svobodných parlamentních voleb, bylo novým vedením Karlovy univerzity stanoveno, že mají proběhnout volby vedoucích kateder, studentskou kandidátkou byla právě dr. Emmerová.

Onen první půlrok po pádu komunismu byl překotný a vzrušující a všichni, kdo ho zažili, si to pamatují. Komunisté a jiné prorežimní opory na fakultě se chvíli báli, co s nimi bude, zda nebudou muset ze svých pozic odejít. Sametovost změn však byla, jak známo, tak velká, že se málokomu zkřivil vlásek na hlavě a vše pokračovalo ve vyjetých kolejích s tím, že padly jen ty nejokatější ideologické předpisy, přestaly se vyučovat předměty jako dějiny mezinárodního dělnického hnutí a vědecký ateismus. Mohlo se nyní hovořit svobodně o čemkoli, byly zrušeny indexy tzv. zakázaných autorů a to vše bylo samozřejmě skvělé.

Moje vzpomínky na dr. Emmerovou z těchto prvních šesti měsíců svobody jsou kusé. Setkávali jsme se víceméně náhodně na půdě katedry a vždy jsme živě probírali politickou situaci. Vzpomínám si ale, že dr. Emmerová okamžitě myslela i na to, jak zkvalitnit jazykovou výuku studentů, a hned, jakmile to bylo možné, se zasadila o to, aby na katedru byli přijati rodilí mluvčí angličtiny.

Další má vzpomínka se týká jedné knihy, na kterou mě dr. Emmerová upozornila. Po revoluci jsem začal vést semináře anglické literatury pod vedením doc. Masnerové, která anglickou literaturu na KPT přednášela. Můj seminář začínal v literatuře ne příliš nakloněnou dobu, v 7:30 ráno. Setkával jsem se na něm s hrstkou studentek tlumočnictví. Jednoho rána jsem přišel učit a dosud poněkud zamlženým zrakem na svém stole spatřil knihu Malcolma Bradburyho Why Come to Slaka? s lístkem od dr. Emmerové, at se na tu knížku podívám, že je to zábavné. Studentky ještě nepřišly, tak jsem knihu otevřel a po několika přečtených odstavcích jsem se, ač v místnosti sám, hlasitě rozchechtal. Kniha byla fiktivním průvodcem po smyšlené socialistické zemi jménem Slaka. Napsaná úmyslně jazykem imitujícím angličtinu klopotně přeložených jídelních lístků a průvodců pro těch pár anglicky mluvících turistů, kteří sem v dobách komunismu přijeli. Kniha doprovozená rozmazanými fotkami otlučených paneláků dokazujícími úspěchy socialismu. Bylo to k popukání. Připadalo mi skvělé, že už se pomalu z té naší „Slaky“ vyhrabáváme ven a podobnou knihu nemusíme skrývat před všudypřítomnými udavači. Pokusil jsem se pak studentkám pro oživení semináře o siru Walteru Scottovi pár obzvláště vtipných kousků z Bradburyho knihy přečíst. Nesetkalo se to tenkrát s valným úspěchem. Ty studentky skutečně považovaly literaturu jen za nutné zlo.

V červnu 1990 se konaly na katedře, stejně jako na jiných katedrách FF UK, volby šéfů kateder. Studenti tehdy měli při této volbě velké slovo. Kandidáti byli dva. Profesor Hrala a doktorka Emmerová. Ta měla převažující podporu studentů. Pár dnů před volbou se celá katedra, vyučující i studenti, sešla ve velké učebně v Hybernské a kandidáti měli přednést své předvolební projevy. Ještě než na ně došlo, vzala si slovo sekretářka katedry a obvinila mě přede všemi, že podle ní neprrípustně agituji mezi studenty pro dr. Emmerovou. Byl to pro mě trochu blesk z čistého nebe. Ještě den před tím se ke mně chovala nadmíru přátelsky a ukazovala mi nadšeně básničku, kterou jí na hospodský účet 
načmáral Martin Jirous (zřejmě aby doložila, že i ona jde s dobou a přátelí se ted', když už se to smí, s lidmi z undergroundu). Najednou byl její přátelský tón pryč a bojovala jako lvice za profesora Hralu. Vstal jsem a řekl, že je to pravda a otevřeně jsem přítomné studenty vyzval, at volí dr. Emmerovou, protože není na rozdíl od profesora Hraly spjata s minulým režimem.

Začaly projevy. Jako první hovořil profesor Hrala. Na stole před sebou měl naskládané své vědecké publikace o ruské a sovětské literatuře a hovořil o svých akademických zásluhách i zásluhách pro Katedru překladatelství a tlumočnictví, kterou vedl od sedmdesátých let. Bylo vidět, že je zvyklý mluvit na veřejnosti, že je schopen bojovat o svou pozici šéfa katedry a že vůbec nepovažuje za nemístné hlásit se o tuto funkci i v této tak radikálně proměněné době.

Přišla na řadu dr. Emmerová. Řekla něco v tomto smyslu: „Nemohu se zde prezentovat akademickými díly, jako profesor Hrala, nebot', jak asi řada z vás ví, mi celou dobu mého působení na KPT v 70. a 80. letech bylo bráněno v akademickém postupu. Na KPT jsem byla odsunuta $\mathrm{z}$ anglistiky na hlavní budově kvưli svým politickým názorům a přátelství s Josefem Škvoreckým. Dokladem mé odborné způsobilosti jsou mé překlady, které mám v kufru doma pod postelí.“ Následovala věta, která všechny přítomné překvapila, v níž se dr. Emmerová vzdala kandidatury na post vedoucí katedry.

Dr. Emmerová nebyla z rodu bojovníků o posty a pozice. Neměla na pokračování v předvolebním boji prostě žaludek. Její rozhodnutí z voleb odstoupit bylo pochopitelné a zároveň smutné, protože kdyby kandidaturu nepoložila, zcela jistě by vyhrála, nebot' většina studentů byla na její straně. Jak známo, volby pak vyhrála a na dlouhá léta se vedoucí katedry stala dr. Jettmarová.

Paní doktorka Emmerová však dokázala bojovat na jiných kolbištích. Někdy na začátku 90. let vznikl spor o to, kdo přeložil knihu Prezydent Krokadýli̊. Oficiálně ji přeložil Jan Zábrana, avšak Josef Škvorecký se k autorství překladu po svém př́ijezdu z exilu přihlásil a tím rozpoutal léta trvající rozepře na české literární a překladatelské scéně. Vzpomínám si, jak těžce tyto spory doktorka Emmerová nesla. Právě proto, že Zábranu i Škvoreckého dobře a dlouho znala a s oběma se přátelila. V té době Jan Zábrana již nežil, za jeho autorství bojovala vdova po něm, paní Marie Zábranová. Vzpomínám si, jak dr. Emmerová opakovaně na toto téma hovořila a vždy se velmi zastávala Škvoreckého verze, tzn. Škvoreckého autorství tohoto překladu, v rozhovorech s lidmi i v tisku. Možná si nebyla jistá, zda má vést katedru, ale čím si jistá byla, za to byla schopna bojovat.

Dr. Emmerová mě od první chvíle, kdy jsem se s ní seznámil, okouzlovala svou otevřeností a mladým duchem. Zároveň jsem ji poznal jako ženu věrnou svým zásadám a přátelům, vzdálenou všemu lavírování. Je z těch lidí, které neopustila zvídavost, kteří nemají předem utvořené názory, a naopak se nikdy nepřestávají ptát a zajímat o dění kolem sebe. Někdo je starý už ve dvaceti a někdo je naopak mladý v devadesáti. K těm druhým rozhodně patři dr. Emmerová a já jsem vděčný za to, že jsem měl možnost být, byt jen čtyři semestry, jejím kolegou. 